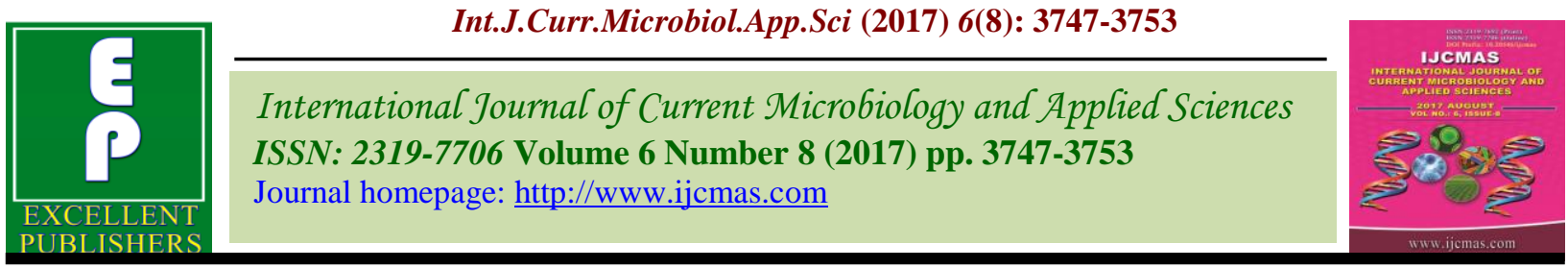

Original Research Article https://doi.org/10.20546/ijcmas.2017.608.452

\title{
Preservation of Apricot Jams (Prunus armeniaca L.) Under Ambient Temperature of Cold Arid Region
}

\author{
R.A. Wani ${ }^{1}$ *, Sunam Sheema ${ }^{2}$, S.A. Hakeem ${ }^{1}$, Jahangeer A. Baba ${ }^{1}$ Umar I. $^{1}$, A.H. Pandit ${ }^{3}$, \\ M.A. Mir ${ }^{3}$, Tanveer-ul-Hassan ${ }^{4}$, K.M. Bhat ${ }^{3}$, Sabiya Bashir ${ }^{1}$, Seerat-u-Nissa ${ }^{1}$, Yusra Amin \\ Basu $^{1}$, Insha Nazir ${ }^{6}$, Sabahat Rafique Qazi ${ }^{6}$ and G.A. Parray ${ }^{5}$ \\ ${ }^{1}$ Dry Land Agriculture Research Station, Budgam, SKUAST-K Kashmir, J \& K, India \\ ${ }^{2}$ Department of Integrated Child Development Scheme, Jammu and Kashmir, J \& K, India \\ ${ }^{3}$ Division of Fruit Science, SKUAST-Kashmir, J \& K, India \\ ${ }^{4}$ Department of Agriculture, Jammu and Kashmir, J \& K, India \\ ${ }^{5}$ High Altitude Rice Research Station, Khudwani, SKUAST-K Kashmir, J \& K, India \\ ${ }^{6}$ Kashmir University Hazratbal Srinagar \\ *Corresponding author
}

\section{A B S T R A C T}

\begin{tabular}{|l|}
\hline Ke y w o r d s \\
Apricot jams, \\
Sugar \\
concentrations, \\
Preservation, \\
Shelf life, \\
Ambient \\
temperature. \\
\hline Article Info \\
\hline $\begin{array}{l}\text { Accepted: } \\
\text { 21 June } 2017 \\
\text { Available Online: } \\
\text { 10 August } 2017\end{array}$ \\
\hline
\end{tabular}

Apricot (Prunus armeniaca L.), a member of Rosaceae family, is a stone fruit with an enlarged mesocarp of the ovary wall being the edible part. Storage conditions are very important factor for jam quality. Apricot is a climacteric fruit with a very short storage life due in part to a high respiration rate and a rapid ripening process. Thus in order to reduce post-harvest losses, numerous techniques and processes for fruit conservation into jam, jelly, marmalade, as well as nectar has been developed. The objective of this study was to monitor the physico-chemical stability and sensorial profile of apricot jam during storage for 80days. The studies were based on variations of sugar and to find out the best treatment for maximum storage period. The experiment comprised of 5 levels of addition of sugar and data obtained was analyzed by completely randomized design. Results obtained from study showed that Treatment $3(1000 \mathrm{~g}$ pulp $+1000 \mathrm{~g}$ sugar) possessed an ideal value of total soluble solids (TSS), pH, acidity, moisture, ascorbic acid, and overall acceptability at $0,20,40$ and 80 days of storage. These seven parameters show that the quality of Apricot Jam obtained by incorporating $1000 \mathrm{~g}$ of sugar was of good texture and quality. Based on the experimental study it was concluded that among all the treatments, treatment 2 was the best with regard to physical, chemical and sensory parameters of jam.

\section{Introduction}

The Latin word furor meaning "I delight in" is the source of word fruit. Fruits are essential in human diet as they contain compounds of nutritional importance, including vitamins that are not synthesized by the human body. Fruits are defined as the reproductive organs arising from the development of floral tissues with or without fertilization. Apricot fruit (Prunus armeniaca L.) is the specie of prunus, classified with the Prunoidae sub family of Rosaceae, family of Rosales (Hyder et al., 2007). The apricot is native to central and western China. Apricot is cultivated almost all over the world but Turkey is the largest world's largest producer of apricot accounting for $20 \%$ of world production. In India major Apricot producing states are Jammu and Kashmir, Himachal Pradesh and 
Uttaranchal. It is a stone fruit with an enlarged mesocarp of the ovary wall being the edible part. The pit or stone consists of endocarp whereas exocarp constitutes the skin of the fruit. The true seed is found enclosed within the endocarp. The fruit is nearly smooth and is of orange or yellow color. Apricots can be successfully grown at an altitude between 900 and $2000 \mathrm{~m}$ above mean sea level. White fleshed, sweet kernelled apricots require cooler climate and are grown in dry temperate region up to $3000 \mathrm{~m}$ above mean sea level.

Fruits are amongst the first food items known consumed prehistorically by human beings. Fruits whether fresh, dried or processed have always formed an essential part of the staple diet of human beings because they are rich in nutrients and provide some of the essential minerals, vitamins, and the like, apart from that, they also help in curing a number of diseases. Apricot is a fruit of dry areas containing fair amount of vitamin $\mathrm{A}$ and also contains significant amount of several minerals including iron, calcium, phosphorus and copper. Nutrionally apricot is a rich source of sugars, fibers, minerals and vitamins like thiamine, riboflavin, niacin and pantothenic acid (Sartaj et al., 2011). In addition apricot fruit is known to contain appreciable amount of carotenoids mainly (beta-Carotene) and bioactive photo chemicals such as chlorogenic, caffeic, pcoumaric and ferulic acids (Dragovic-Uzelac et al., 2007). Each apricot has about 20 calories. Three medium apricots equal one third daily requirement of vitamin A. Apricot fruits contain nutrients which can help in protection of heart and eyes, as well as diseases fighting effects of fiber. The betacarotene and lycopene activity of apricots may prevent the heart disease Apricots are a good source of fiber, which has a wealth of benefits such as prevent digestive condition called diverculosis. These fruits are antipyretic, antiseptic, emetic and ophthalmic (Pramer et al., 1982). The world production of apricot has increased considerably during the last 20 years. Indeed the production doubled from 1.2 million times in 1992 to 2.3 million tonnes in 2010. Apricot, the $16^{\text {th }}$ cultivated fruit in the world, is largely cultivated in Mediterranean region (FAO, 2010).

Apricot is a perishable fruit having 3-5 days of storage life at optimum conditions and 2-4 weeks at cold storage. The storage life varies with variety. The short storage life of this fruit is due to short time period for commercial ripening to the degradation process characteristic like senescence (Agar et al., 1993, Egea et al., 2007). Historically, jams originated as an early effort to preserve fruit for consumption during off season. It is an intermediate moisture food prepared by boiling fruit pulp with sugar, pectin, acid and other ingredients until obtaining a thick consistency. Ripe apricot fruit contains pectin therefore it is used in making jam and jelly which are of great demand in international market. According to FPO specifications, a jam should contain a minimum of $68 \%$ TSS in the final product and the fruit content in the final product should not be more than $45 \%$ (w/w).

Preservation is a way to keep fruits for longer duration as it prevents the food from decay and spoilage. Preservation of Apricot jam in glass jars, which cannot be hermetically sealed is rather difficult, as the surface of the jam in the jar is susceptible to mould growth and after moisture evaporation from the jam resulting in surface graining and also shrinkage of jam.

Developing countries are being encouraged to diversify their food exports by developing new products and adding more value to existing products. In India bulk of Apricots 
are produced in Arid Ladakh region of Jammu and Kashmir and there is quarantine restrictions for sale of fresh apricots outside Ladakh region due to codling moth disease. High concentration of sugar facilitates storage (Tari, et al., 1989 and Bhandari, 2004) as such it was suggested to determine the best treatment of sugar variation in apricot jam for maximum storage. Generally fruit jam storage at high temperature leads to significant decrease of nutritive value and sensorial properties (Wicklund et al., 2005; Vidya et al., 2011). To our knowledge, the literature available at present is poor in references of apricot jam properties during storage in different conditions (Aslanoya et al., 2010; Rbabeh et al., 2011).

Thus the aim of this research is focused on the assessment and monitoring of physicochemical parameters and organoleptic quality of apricot jam during storage.

\section{Materials and Methods}

The experimental work was conducted in the laboratory of Regional Agriculture Research Station Leh (now HMARRI Leh) 2010-11. There were five treatment combinations and experiment was laid out in completely Randomized block design with three replications. The fruits selected for processing purpose were crushed mechanically and the pulp collected was subjected to boiling and concentrated by adding sugar till the end point was judged through drop test, TSS (68-70\%) and by sheet test.

Different concentrations of sugar like $800 \mathrm{~g}$, $900 \mathrm{~g}, 1000 \mathrm{~g}, 1100 \mathrm{~g}$ and $1200 \mathrm{~g}$ were added to $1.0 \mathrm{Kg}$ of fruit pulp as treatment 1 , treatment 2 , treatment 3 , treatment 4 and treatment 5 respectively. The observations were recorded on physical characteristics like $\mathrm{pH}$, TSS, Acidity, moisture, ascorbic acid, iron content and physical parameters like texture, flavor, color, appearance, taste, after taste and over all acceptability.

\section{Results and Discussion}

All the treatments in the present investigation had significant impact for all observed traits. However, treatments differed significantly from one another at various time intervals in tables 1, 2 and figures 1,2). Among the chemical parameters observed $\mathrm{pH}$, moisture content, ascorbic acid content and iron content showed a gradual decline whereas total soluble solids, total acidity registered a subsequent increase. Similar results were also obtained by Karhasushenko 1998; Pino J et al., 2004; Arthey et al., 2005 and Wani et al., 2013. $\mathrm{pH}$ of all the treatments underwent a decrease during preservation because of an increase in overall acidity of jam during preservation. All the treatments showed better values of $\mathrm{pH}$ during storage but the treatment 4 showed an ideal values of $\mathrm{pH}$ during storage thus indicating $1000 \mathrm{~g}$ of sugar may be recommended for $1 \mathrm{~kg}$ of Apricot pulp as jam at this $\mathrm{pH}$ possesses a good setting property. The hydrogen ion concentration indicates strength of jam. There was a regular decrease of $\mathrm{pH}$ value of all the treatments during storage. Similar findings were also obtained by some other scientists Baker, 1989; Joseph, 1994; Lal, G et al., 1998; Singh, et al., 2008 and Wani et al., 2013. In apricot main sugar is sucrose (Wills et al., 1983) the amount of sugars drastically increased during ripening of fruit because all of starch is fully hydrolyzed TSS of all treatments underwent an increase because of breakdown of complex sugar in to simple sugar during the period of preservation. TSS of treatment 3 was found to be ideal during the period of storage in table 1 and figure 1. Jam at this TSS possesses a firm texture, excellent body and sweet taste. Observations showed a subsequent increase in TSS values for all the treatments during storage. (Ashraf, 1987, and Wani et al., 2013) 
also reported similar results in different studies. Titrable acidity is directly related to the concentration of organic acids present in the fruit. Organic acids exist as free acids, anions (malate) or combined as salt (potassium bitartrate) and esters such as isopropyl acetate (Keys, 1991) Total Titrable acidity determines the strength of jam and there was a subsequent increase in total acidity of jam during preservation and acidity of treatment 3 was found in accurate range (Table 1). Jam at this titrable acidity possesses a firm texture and good setting property. Similar results were reported by (Wang 1999 and Singh, et al., 2000 and Wani et al., 2013). Moisture content of all the treatments decreased during preservation and increased with enhancement of sugar concentration in Apricot pulp. All the treatments registered better water activity values and the best water activity values were recorded for treatment 3 and treatment 4 . The water content of jam directly controls chemical reaction rates and microbial activity. These findings are supported by different research works reported by (Gordon, et al., 2000, Nayak et al., 2011 and Wani et al., 2013). Ascorbic acid content showed a gradual decrease during preservation because of breakdown of ascorbic acid by antiascorbic acid compounds. The decreasing trend of ascorbic acid with the advancement of storage period might be due to conversion of dehydroascorbic acid to diketogluconic acid by oxidation (Rai and Saxena, 1988 and Lee et al., 2000) the maximum ascorbic acid content was found in treatment 3 as shown in table 1 and figure 1 indicating ideal sugar concentration. Similar results were obtained by Upasana et al., (1985), Joshi (1986), Lee et al., (2000), Arthey et al., (2005) and Wani et al., (2013).

Table.1 Chemical parameters of Apricot jam during storage at ambient temperature

\begin{tabular}{|c|c|c|c|c|c|c|c|c|c|c|c|c|c|c|c|c|c|c|}
\hline \multirow[t]{2}{*}{$\begin{array}{l}\text { Treat } \\
\text { ments }\end{array}$} & \multicolumn{3}{|c|}{$\begin{array}{c}\mathrm{pH} \\
\text { Days after storage }\end{array}$} & \multicolumn{3}{|c|}{$\begin{array}{c}\text { Total Soluble Solids } \\
(\%) \\
\text { Days after storage }\end{array}$} & \multicolumn{3}{|c|}{$\begin{array}{c}\text { Acidity (\%) } \\
\text { Days after storage }\end{array}$} & \multicolumn{3}{|c|}{$\begin{array}{c}\text { Moisture (\%) } \\
\text { Days after storage }\end{array}$} & \multicolumn{3}{|c|}{$\begin{array}{c}\text { Ascorbic Acid } \\
(\mathrm{mg} / 100 \mathrm{~g}) \\
\text { Days after storage }\end{array}$} & \multicolumn{3}{|c|}{$\begin{array}{c}\text { Iron content } \\
(\mathrm{mg} / \mathbf{1 0 0 g}) \\
\text { Days after storage }\end{array}$} \\
\hline & 0 & 40 & 80 & 0 & 40 & 80 & 0 & 40 & 80 & 0 & 40 & 80 & 0 & 40 & 80 & 0 & 40 & 80 \\
\hline T1 & 3.7 & 3.6 & 3.4 & 66 & 68 & 69 & 0.75 & 0.78 & 0.80 & 21 & 18 & 16 & 3.7 & 3.4 & 3.1 & 36.7 & 35.2 & 32.6 \\
\hline $\mathbf{T 2}$ & 3.6 & 3.5 & 3.5 & 67 & 69 & 71 & 0.74 & 0.76 & 0.78 & 22 & 19 & 18 & 3.5 & 3.2 & 2.9 & 36.0 & 35.3 & 32.7 \\
\hline T3 & 3.7 & 3.6 & 3.5 & 68 & 70 & 72 & 0.74 & 0.76 & 0.78 & 23 & 21 & 20 & 4.0 & 3.7 & 3.5 & 37.0 & 35.9 & 33.3 \\
\hline T4 & 3.7 & 3.6 & 3.6 & 69 & 71 & 72 & 0.73 & 0.76 & 0.77 & 24 & 22 & 20 & 3.5 & 3.2 & 2.9 & 36.0 & 35.4 & 30.8 \\
\hline T5 & 3.8 & 3.6 & 3.5 & 70 & 71 & 73 & 0.72 & 0.75 & 0.76 & 22 & 20 & 18 & 3.8 & 3.5 & 3.4 & 37.0 & 35.4 & 32.7 \\
\hline $\begin{array}{l}\text { SEM } \\
\pm\end{array}$ & 0.09 & 0.07 & 0.11 & 1.3 & 1.24 & 0.67 & 0.01 & 0.01 & 0.01 & 0.63 & 0.6 & 0.75 & 0.10 & 0.06 & 0.09 & 0.07 & 0.20 & 0.11 \\
\hline $\begin{array}{l}\text { CD at } \\
5 \%\end{array}$ & 0.21 & 0.16 & 0.27 & 3.0 & 2.89 & 1.53 & 0.02 & 0.02 & 0.27 & 1.45 & 1.4 & 1.73 & 0.24 & 0.14 & 0.21 & 0.17 & 0.20 & 0.11 \\
\hline
\end{tabular}

Table. 2 Sensory parameters (storage period marks according to 9 point Hedonic scale) of Apricot jam during storage at room temperature

\begin{tabular}{|c|c|c|c|c|c|c|c|c|c|c|c|c|c|c|c|c|c|c|}
\hline \multirow[t]{2}{*}{ Treatments } & \multicolumn{3}{|c|}{$\begin{array}{l}\text { Texture } \\
\text { Days after storage }\end{array}$} & \multicolumn{3}{|c|}{$\begin{array}{l}\text { Flavor } \\
\text { Days after storage }\end{array}$} & \multicolumn{3}{|c|}{$\begin{array}{l}\text { Color and } \\
\text { appearance } \\
\text { Days after storage }\end{array}$} & \multicolumn{3}{|c|}{$\begin{array}{l}\text { Taste } \\
\text { Days after storage }\end{array}$} & \multicolumn{3}{|c|}{$\begin{array}{l}\text { After taste } \\
\text { Days after storage }\end{array}$} & \multicolumn{3}{|c|}{$\begin{array}{l}\text { Overall } \\
\text { acceptability } \\
\text { Days after } \\
\text { storage }\end{array}$} \\
\hline & $\mathbf{0}$ & 40 & 80 & $\mathbf{0}$ & 40 & 80 & $\mathbf{0}$ & 40 & 80 & 0 & 40 & 80 & 0 & 40 & 80 & $\mathbf{0}$ & 40 & 80 \\
\hline T1 & 5.09 & 6.71 & 6.31 & 6.31 & 6.61 & 7.31 & 6.39 & 6.61 & 7.39 & 5.00 & 5.39 & 6.31 & 5.61 & 6.61 & 7.19 & 5.11 & 6.31 & 7.49 \\
\hline T2 & 5.70 & 7.00 & 7.00 & 6.31 & 7.00 & 7.31 & 6.61 & 7.31 & 7.69 & 5.66 & 7.09 & 7.69 & 6.31 & 6.66 & 7.39 & 5.21 & 5.11 & 7.31 \\
\hline T3 & 6.81 & 7.93 & 8.83 & 7.83 & 8.63 & 8.99 & 7.39 & 8.09 & 8.61 & 7.31 & 8.19 & 8.99 & 7.61 & 8.00 & 8.99 & 7.11 & 8.33 & 8.99 \\
\hline T4 & 6.31 & 6.50 & 6.56 & 7.00 & 7.61 & 7.31 & 7.31 & 7.61 & 7.91 & 7.31 & 7.61 & 7.91 & 6.61 & 6.81 & 7.69 & 6.39 & 7.19 & 8.11 \\
\hline T5 & 6.00 & 5.31 & 6.00 & 5.00 & 6.00 & 5.69 & 6.69 & 7.31 & 7.69 & 7.09 & 7.31 & 7.69 & 6.00 & 6.31 & 7.39 & 5.19 & 6.11 & 7.21 \\
\hline SEM \pm & 0.59 & 0.36 & 0.57 & 0.53 & 0.39 & 0.58 & 0.59 & 0.94 & 0.35 & 0.54 & 0.38 & 0.43 & 0.37 & 0.43 & 0.39 & 0.51 & 0.65 & 0.60 \\
\hline CD at $5 \%$ & 0.27 & 0.81 & 1.31 & 1.19 & 0.91 & 1.04 & 1.37 & 1.05 & 0.81 & 1.26 & 0.89 & 0.02 & 0.85 & 0.97 & 0.90 & 1.19 & 1.51 & 1.39 \\
\hline
\end{tabular}


Fig.1 Chemical parameters of Apricot Jam during storage at ambient temperature

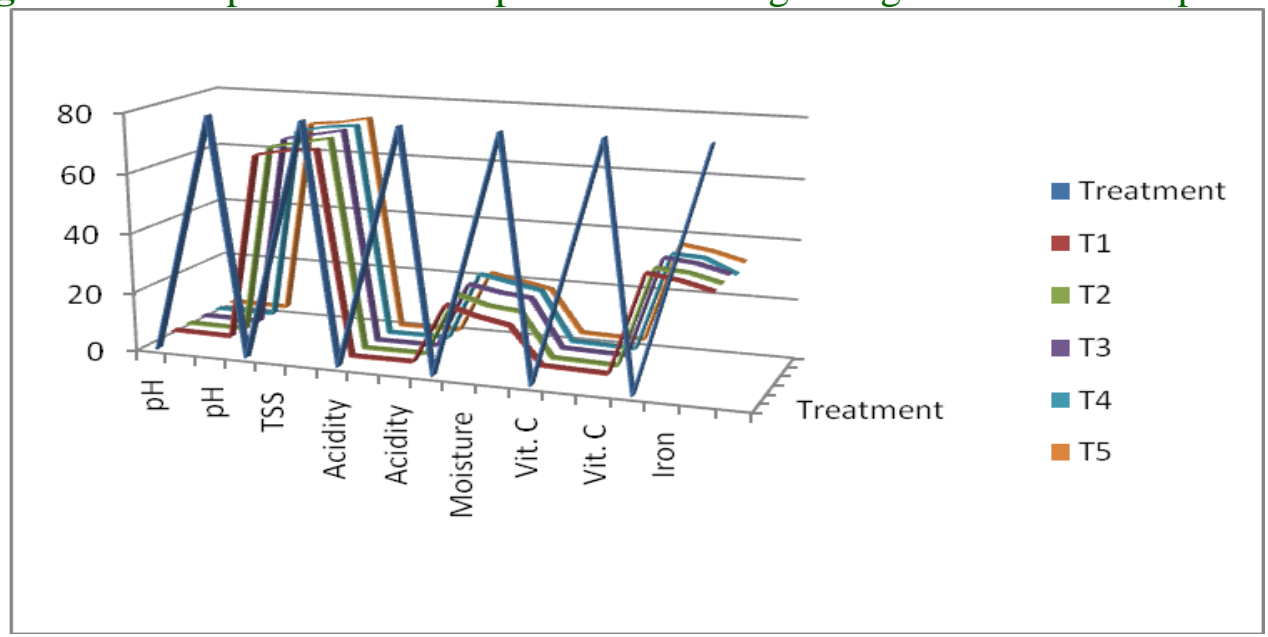

Fig.2 Sensory parameters (storage period marks according to 9 point Hedonic scale) of Apricot Jam during storage at ambient temperature

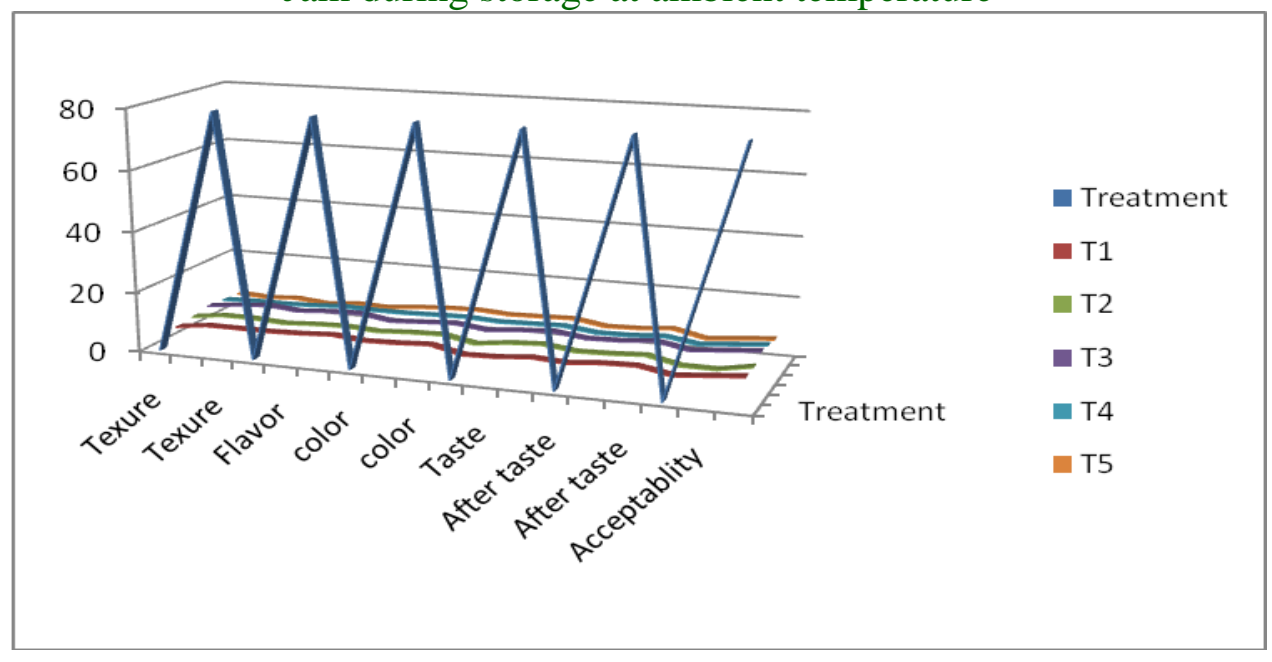

The appearance is a major determent of quality. The color of fruit is contributed by plant pigments, which are classified into four main categories based on their chemistry chlorophylls, carotenoids, flavonoids and betalains. Data pertaining to color score in table 2 and figure 2 revealed that apricot jam showed gradual increase of color score. Due to degradation of chlorophyll the carotenoid pigments become visible. These results are in agreement with Wills et al., (1989) and Wani et al., (2013) Taste is one of the important sensory properties which are attributed to the presence of certain soluble constituents of the food that reaches to the sensitive taste buds. It is relatively simple sense producing only four types of sensation-those of contributing to the flavor characteristics in fruits. These are organic acids, sugars, bitter and volatile constituents. The organic acids are usually citric, malic and these provide tartness in flavor. The sugars contribute sweetness and bitter related to phenol compounds. The overall acceptability score was increased to a certain limit with the passage of storage period as shown in table 2 and figure 2. The improvement in overall acceptability score of apricot jam might be due to metabolical changes occurring in structural polysaccharides, sugars and organic acids etc. The sensory parameters like texture, color, flavor, 
appearance, taste, after taste and overall acceptability showed significant increase during preservation. All the treatments were awarded better score by a panel of 7 judges but the treatment 3 got the best score (Table 2 and Figure 2). The score card is based on the 9 point Hedonic Scale. Thus the sensory quality of the jam increased during the period of storage. Overall acceptability of jam incorporated with $1000 \mathrm{~g}$ of sugar was found to be liked extremely on Hedonic scale in comparison to other treatments during preservation. Similar results were reported by (Tandon et al., 2003; Pino et al., 2004; Singh et al., 2005 and; Wani et al., 2013).

From the present findings it is concluded that Apricot, which is the main fruit of arid region India can be utilized for making jam and this jam can be stored for at least three months without undergoing any deterioration and evidently Treatment 3 i.e. $1 \mathrm{Kg}$ Apricot pulp + $1000 \mathrm{~g}$ sugar showed the best results with regard to physical, chemical and sensory parameters of jam.

\section{References}

Agar, I and A Polate, 1995. Effect of different packing material on the storage quality of some apricot varieties. Acta Hort., 384: 625-631.

Arthey, D and R A Philp, 2005. Fruit processing nutrition, product and quality management, Ed $2^{\text {nd }}$ Brijbasi Art Press Ltd. India. pp: 45.

Ashraf, S.N (1987). Studies on post-harvest technology of Jamun Fruit. PhD Thesis N.D. University of technology Faizabad (U.P).

Aslanoya D., 2010; Bakkalbasi, E and Atok, N. (2010). Effect of storage on5hydroxymethylfurfural formation and color change in jams. International journal of Food properties, 13,904-912.

Baker, G.L. (1989). High polymer pectin's and their desertification. Advances in food Research, 1, 395.
Bhandari, S. P. 2004, Studies on physicochemical composition, grading, storage and processing of jamun (Syzygium cuminii (Linn.) Skeels). M.Sc. (Agri.) Thesis, Dr. Balasaheb Sawant Konkan Krishi Vidyapeeth, Dapoli, Dist. Ratnagiri, Maharashtra.

Dheeraj Singh, Lobsang Wangshu and V. C. Prahalad 2008. Processing and marketing feasibility of underutilized fruit species of Rajasthan. Contributed paper presented at IAMO fórum 2008.

Dragovic-Uzelac, V., Levaj, B., Mrkic, V., Burasic, D and Marija Boras, M.2007.The contentof polyphenols and carotenoids in three apricot varieties depending on stage of maturity and geoghraphical región. Food Chemistry, 102, 966-975.

Egea M., Martinez-Madrid., Sanchez- Bel P., Murcia M., Romojaro F 2007. The influence of electric-beam ionizationon ethylene metabolismand quality parameters in apricot .LWT- Food Science and Technology, 2007; 40(6): 1027-1035.

FAO, 2010. Food and agricultura organización of the United Nations.

Gordon, D.L., Schwenn, K.S., Ryan A.L., Roy S. 2000.Gel products fortified with calcium and method of preparation. United States Patent. 6077557.

Hyder, H., G Ibrahim, O M Mehmet and M Bayram, 2007. Post-harvest chemical and physical-mechnical properties of some apricot varieties cultivated in Turkey. J Food Eng., 79: 364-373

Joseph, G.L. (1994). Better pectin, Food Engineering, 23, 71.

Joshi, G. D., Prabhudesai, V. G. and Salvi, M. J. 1986, Physico-chemical characteristics of Karonda (Carissa carandas L.) fruits. Maharashtra J. Hort., 3 (1): 39-44.

Karhasushenko (1998). Changes in the chemical properties of jam during storage. Khelbopekarnayai Kanditerskaya, Promyshlennost, 7, 26-27.

Keys S J (1991), Post-harvest physiology of perishable plant products. Vas Nostrand Rein Hold Book, AVI Publishing co., 149316. 
Lal, G., Siddappa, G. S. and Tandon, G. L. 1998. Preservation of fruits and vegetables. ICAR Publication, New Delhi, India.

Lee S K and A A Kedar, 2000. Preharvest and Post-harvest factors influencing vitamin $\mathrm{C}$ content of horticulture crops, Post-harvest Biol. Technol., 20: 207-220.

Nayak P, Bhatt DK, Shukla DK, Tandon DK (2011). Evaluation of aonla (Emblica Officinalis G.) segments-in-syrup prepared from stored fruits. Res. J. Agric. Sci., 43(2).

Pino, J., R. Marbot, C. Vazques. (2004) Volatile flavour constituents of Karnda (Carissa carandas L.) Fruit.Journal of Essential Oil Research.16 (5): 432-4.

Pramer, C and M K Kaushal, 1982.Wild fruits of sub Himalayan región. Kalyani Publishers New Delhi India.

R A Wani, V M Prasad, S A Hakeem, S Sheema, S Anchuk and Alka Dixit (2013). Shelf life of Karonda Jam under ambient temperatura. African Journal of Agriculture Research, Vol 8, (21) pp. 2447-2449.

Rbabeh, T. M. Al- Mahesnah, M A., Killani, I., Yang, W., Alhamad, M, N., Ereifej, K., 2011. Effect of jam Processing and storage on total phenolics, antioxidant activity and anthocyanins of different fruits. Journal of the Science of Food and Agriculture, 91, 1096-1102.

Sartaj, A., Tariq, $\mathrm{M}$ and Kashifsarafraz, A. 2011. Physico-chemical characteristics of apricot grown in the nortern area of Pakistan. Scentia Horticulturae. 130, 386392.

Singh B P, Pandey G, Pandey MK, Pathak RK (2005). Shelf life evaluation of aonla cultivars. Indian J. Hort., 62(2): 137-140.
Singh, R. and Kumar, S. 2000. Studies on the effect of post-harvest treatments on decay loss and biochemical changes during storage of aonla (Emblica officinalis G.) fruit cv. Chakaiya. Haryana Journal of Horticultural Sciences 29 (3): 178-179.

Tandon D.K; Yadav RC; Sood S; Kumar S and Dixit A (2003). Effect of blanching and lye peeling on the quality of aonla candy. Indian Food Packer, 57(6): 147-152.

Tarr, L.W. and Baker G.L. (1985). Fruit jellies, the role of sugar. University Delaware Agriculture Experimental Station, TechnicalBulletin, 11, 3 .

Upasana Rani and Bhatia, B.S. (1985). Studies on pear Candy processing. India Food Pack, 39, 40-46.

Vidya, R and Narain, A. 2011. Formulation and evaluation of preserved products utilizing under exploited fruit, Wood Apple. American-Eurasean journal of Agriculture and Environmental Sciences, 10, 112-118.

Wang,C. Y. (1999). Post-harvest quality decline, quality maintenance and quality evaluation, Acta Hort, ISHS, 485: 389392.

Wicklund, T., Rosenfeld, H J., Martinsen, B. K., Sundfor, M W., Lea, P., Bruun, T.2005. Antioxident capacity and color of strawberry jam as influenced by cultivar and storage conditions. Food science and Technology, 38, 387-391.

Wills, R B H; W B Macglosson; D Graham; T $\mathrm{H}$ Lee and $\mathrm{E} \mathrm{G}$ Hall, 1989. An introduction to the physiology and handling of fruits and vegetables. Oxford, London, Edinburg, Boston, Melbourne. BSP Professional Books

\section{How to cite this article:}

Wani, R.A., Sunam Sheema, S.A. Hakeem, Jahangeer A. Baba, A.R. Malik, I. Umar, Ashaq H. Pandit, M. Amin Mir, Tanveer-ul-Hassan, Sabiya Bashir, Seerat-u-Nissa and Parray, G.A. 2017. Preservation of Apricot Jams (Prunus armeniaca L.) Under Ambient Temperature of Cold Arid Region. Int.J.Curr.Microbiol.App.Sci. 6(8): 3747-3753. doi: https://doi.org/10.20546/ijcmas.2017.608.452 